\title{
Bioremediation of heavy metals from aquatic environment through microbial processes: A potential role for probiotics?
}

\author{
Marie Andrea Laetitia Huët*, Daneshwar Puchooa \\ Department of Agricultural and Food Science, Faculty of Agriculture, University of Mauritius, Réduit, Mauritius
}

\begin{tabular}{|c|c|}
\hline $\begin{array}{l}\text { Article history: } \\
\text { Received on: July } 10,2017 \\
\text { Accepted on: September } 03,2017 \\
\text { Available online: November } 09,2017\end{array}$ & $\begin{array}{l}\text { Heavy metals can cause disastrous effects on any living organisms. Probiotics have the ability to reduce metal toxicity. } \\
\text { Bioremediation of polluted waters using these bacteria could be an alternative to conventional remediation methods. } \\
\text { The aim of this study was to isolate and characterize heavy metal resistant probiotics. Soil samples were collected for } \\
\text { the isolation of probiotics. Morphological, biochemical, and molecular characterization was performed for the isolates. }\end{array}$ \\
\hline $\begin{array}{l}\text { Key words: } \\
\text { Bioremediation, } \\
\text { Probiotics, } \\
\text { Heavy metals, } \\
\text { Enterococcus, } \\
\text { Bacillus acidiproducens }\end{array}$ & $\begin{array}{l}\text { In addition, a preliminary heavy metal minimum inhibitory concentration test was done followed by atomic absorption } \\
\text { spectrometry (AAS) analysis analysis. Four Enterococci (BT1, BT2, MC1, and MC2) and Bacillus acidiproducens } \\
\text { (SM1 and SM2) were isolated. Moreover, all the isolates demonstrated probiotic characteristics. BT1 and BT2 were able } \\
\text { to tolerate mercury (Hg), cadmium (Cd), lead (Pb), and chromium (Cr) but they demonstrated poor } \mathrm{Hg} \text { removal abilities } \\
(0.75-1.42 \%) \text {. MC1 and MC2 isolates could grow in medium supplemented with } \mathrm{Cd}, \mathrm{Pb} \text {, and } \mathrm{Cr} \text {, respectively. MC1 } \\
\text { showed the highest level of Pb removal }(43.00 \% \pm 0.776 \%) \text { and } \mathrm{Cd} \text { removal }(46.19 \% \pm 7.651 \%) \text { from broth media. } \\
\text { Yet, SM1 and SM2 isolates tolerated only } \mathrm{Pb} \text { and } \mathrm{Cr} \text {. SM2 had the ability to remove the highest amount of } \mathrm{Cr} \text { ( } 43.06 \% \\
\pm 7.991 \%) \text {. These reasonable heavy metal removal abilities could be further studied for efficient use in bioremediation. }\end{array}$ \\
\hline
\end{tabular}

\section{INTRODUCTION}

Heavy metals can be defined as a group of forty elements with a density higher than $5 \mathrm{~g} / \mathrm{cm}^{3}$ [1]. Man has been using heavy metals for ages and their use, for industrial purposes, is still predominant in the developing world. However, many of these countries are facing destructive consequences. Heavy metals can cause disastrous effects on all living organisms as well as on the environment. They are said to be hazardous due to their toxicity even at low concentrations. Examples of heavy metals are mercury $(\mathrm{Hg})$, arsenic, cadmium $(\mathrm{Cd})$, Lead $(\mathrm{Pb})$, chromium $(\mathrm{Cr})$, Zinc $(\mathrm{Zn})$, and copper $(\mathrm{Cu})$. Furthermore, heavy metals are nonbiodegradable so they remain in the environment and biological systems.

Some heavy metals occur naturally in ecosystems at very low concentration. Nevertheless, they can enter aquatic environment through natural and anthropogenic sources. These contaminants may easily dissolve in waters, and they tend to bioaccumulate in different aquatic organisms. A majority of the world population depend on

*Corresponding Author

Marie Andrea Laetitia Huët,

Faculty of Agriculture,

University of Mauritius,

Réduit,Mauritius.

Email: laetitia.huet21@gmail.com aquatic ecosystems for food supply. Humans are mainly exposed to metal toxicity by ingestion of contaminated food and water. For these reasons, heavy metal pollution in aquatic systems is becoming a serious threat.

The aquatic environment in Mauritius is mainly affected by heavy metals contamination arising from industrial wastes and contaminated sewage wastewater [2]. Furthermore, it was reported that regions close to Grand River North West were contaminated with $\mathrm{Cu}, \mathrm{Pb}$, and $\mathrm{Zn}$ emerging from vehicles dust and galvanized signs or other equipment found on roads nearby [3].

Several methods exist to remediate heavy metal pollution in waters such as membrane filtration, ion exchange mechanisms, or by precipitation. Yet, these techniques are not cost effective, in some cases, and do produce wastes that need to be properly disposed of. Microbial bioremediation could be an alternative. The use of microbes for remediation of heavy metals has been well studied. Some microorganisms, especially soil bacteria, have the ability to tolerate these contaminants. In addition, certain bacterial strains are capable of binding to heavy metals or transforming them into less toxic forms.

Probiotics are beneficial bacteria found in the gut microbiota. They mainly help in the digestion process and strengthen the immune system within the human body. These probiotics are generally regarded as safe and are commonly used in the dairy industry. Probiotics can also be isolated from different sources in the environment. These bacterial 
Huët and Puchooa: Probiotics and heavy metals 2017;5(6):14-23

species possess several desirable characteristics that can be exploited to benefit human beings as well as the environment.

Lactic acid bacteria are mainly Gram-positive and can be categorized as probiotics. The term lactic acid bacteria are retained for the most important genera in the order Lactobacillales including Lactobacillus, Leuconostoc, Pediococcus, Lactococcus, Streptococcus, Enterococcus, Weissela, and Bifidobacterium [4]. Studies have demonstrated that some strains of lactic acid bacteria were able to reduce the absorption of toxic substances by the gastrointestinal tract [5]. The use of lactic acid bacteria in remediation processes has shown to be effective. Previous studies performed praised the use of lactic acid bacteria in the remediation of heavy metal-contaminated water [6]. Moreover, some of these bacterial species are able to bind to heavy metals due to specific structures found on their cell wall. Their cell wall is made up of peptidoglycan, teichoic, and lipoteichoic acid structures, an S-layer, in some species, and neutral polysaccharides. The teichoic acid structures, the cell wall polysaccharides, and the exopolysaccharides allow adhesion to macromolecules [7]. The aim of this study was to isolate and identify heavy metals resistant probiotics, mainly lactic acid bacteria, from three different metal polluted soils in Mauritius and to determine the absorbing or binding potential of the isolates to four different heavy metals, namely, $\mathrm{Cd}$, $\mathrm{Cr}, \mathrm{Pb}$, and $\mathrm{Hg}$.

\section{MATERIALS AND METHODS}

\subsection{Sample collection}

Soil samples were collected from three metal polluted sites in Mauritius as shown in Table 1. The samples were aseptically placed into sterile corning tubes and transported to the laboratory for further analysis.

\subsection{Methods}

\subsubsection{Preparation of mother sample and serial dilution}

About $1 \mathrm{~g}$ of soil was measured using an electronic balance. The sample was then transferred into $99 \mathrm{ml}$ of sterile physiological saline $(0.85 \%)$. A cotton plug was inserted at the top of the flask, and its content was mixed for about $5 \mathrm{~min}$. Serial dilution was then performed.

\subsubsection{Inoculation on Man, Rosa, and Sharpe (MRS) medium}

The mother sample and the dilutions were plated onto MRS agar (HiMedia, M641) using the spread plate method. The plates were then labeled, sealed with parafilm, and incubated at $37^{\circ} \mathrm{C}$ for $48 \mathrm{~h}$.

\subsubsection{Selection of isolates}

In all, six colonies were chosen (two from each soil sample plated), namely, BT1, BT2, MC1, MC2, SM1, and SM2. The six colonies were streaked separately on MRS agar (HiMedia, M641) and incubated at $37^{\circ} \mathrm{C}$. Sub-culturing was performed twice, on the same medium, to obtain pure cultures. They were then used for further analysis.

\subsection{Morphological Characterization}

The morphology of the six isolates was recorded in tabular form. The following characteristics were assessed: Form, size, surface, texture, color, elevation, and margin.

In addition, staining procedures and tests were performed with the six isolates, namely, Gram staining, acid-fast staining, endospore staining, capsule staining, and bacterial motility test.
Table 1: Collection sites and respective GPS coordinates.

\begin{tabular}{|c|c|}
\hline Site & GPS coordinates \\
\hline Mare Chicose Landfill & $\begin{array}{l}20^{\circ} 23 ' 13.6464 " \mathrm{~s} \\
57^{\circ} 37^{\prime} 50.6532 ” \mathrm{E}\end{array}$ \\
\hline Abandoned Landfill at St. Martin & $\begin{array}{l}20^{\circ} 13^{\prime} 50.5056^{\prime \prime} \mathrm{S} \\
57^{\circ} 26^{\prime} 59.4924^{\prime \prime} \mathrm{E}\end{array}$ \\
\hline Baie-du-Tombeau & $\begin{array}{l}20^{\circ} 77^{\prime} 52.0932 ” \mathrm{~S} \\
57^{\circ} 31^{\prime} 1.6248^{\prime \prime} \mathrm{E}\end{array}$ \\
\hline
\end{tabular}

Source: http://www.latlong.net/

\subsection{Biochemical Characterization}

\subsubsection{Catalase test}

A drop of hydrogen peroxide was placed onto the specimen on a slide. The presence of immediate effervescence was recorded.

\subsubsection{Oxidase test}

The specimen was streaked onto oxidase strips (Oxoid, MB0266). Any color change to purple within 10-15 s was recorded.

\subsubsection{Methyl red test}

The isolate was cultured in MR-VP medium (Oxoid, CM0043). Then, 8 drops of methyl red were added to it. Any color change was observed and noted.

\subsubsection{Voges-Proskauer test}

The isolate was grown in MR-VP medium (Oxoid, CM0043). 12 drops of alpha-naphthol and 6 drops of potassium hydroxide were added to the culture. The tube was vortexed and left to the open air for $20 \mathrm{~min}$. Any color change was observed and noted.

\subsubsection{Starch digestion test}

The isolate was cultured on starch agar (HiMedia, M107S). After an incubation of 7 days at $37^{\circ} \mathrm{C}$, for bacterial growth, the plate was flooded with iodine solution. The observation was made and recorded.

\subsubsection{Carbohydrate fermentation test}

Nutrient broth (Acumedia, 7146) with phenol red indicator was prepared and supplemented with $1 \%$ of glucose, lactose, maltose, and fructose, respectively. The isolate was cultured in the different media. After 7 days of incubation at $37^{\circ} \mathrm{C}$, for bacterial growth, any color change or gas formation was observed and recorded.

\subsubsection{Growth on bile esculin azide agar}

The isolate was streaked onto bile esculin azide agar (HiMedia, M493) and was incubated at $37^{\circ} \mathrm{C}$ for $24 \mathrm{~h}$. Growth and color of medium were recorded following the incubation period.

\subsection{Probiotic Characterization}

\subsubsection{Acid tolerance assay}

The isolate was inoculated in MRS broth (HiMedia, M369) and incubated at $37^{\circ} \mathrm{C}$ for $24 \mathrm{~h} .1 \mathrm{ml}$ of the broth culture was inoculated in MRS broth (control) and acidified MRS broth ( $\mathrm{pH} 3$ ), respectively. An initial absorbance reading was immediately taken at $600 \mathrm{~nm}$ using a light spectrophotometer (JENWAY, 7305). Sterile MRS broth was used as a blank. Absorbance readings were then taken after $24 \mathrm{~h}$. This assay was performed in triplicate. The percentage survival was calculated as follows:

$\%$ Survival $=(\mathrm{OD}$ of control $[$ after $24 \mathrm{~h}] \div$ OD of acidified broth [after $24 \mathrm{~h}]) \times 100$,

Where OD means optical density. 


\subsubsection{Bile tolerance assay}

This assay was performed as described by Arihara et al. [8] with slight modifications concerning the concentrations of bile salts. The isolate was grown in MRS broth (HiMedia, M369) without bile salts at $37^{\circ} \mathrm{C}$ for $24 \mathrm{~h}$. The optical density of the broth was then adjusted to OD600 $=0.1$. A loopful of culture broth was streaked onto MRS agar (Oxoid, CM1153) supplemented with bile salt (Oxoid, LP0055J) at different concentrations $(1000,2000,3000$, and $4000 \mathrm{ppm})$, respectively. The plates were incubated at $37^{\circ} \mathrm{C}$ for $48 \mathrm{~h}$. Bacterial growth was then assessed as good $(++)$, poor $(+)$, or no growth $(-)$. This assay was performed in triplicate.

\subsubsection{Antibiotic resistance assay}

The isolate was grown in MRS broth (HiMedia, M369) at $37^{\circ} \mathrm{C}$ for $24 \mathrm{~h}$. The optical density of the tube was then adjusted to OD600 = $0.1 .1 \mathrm{ml}$ of culture broth was spread onto MRS agar (Oxoid, CM1153). Antibiotic discs were then placed on the prepared MRS agar plates, which were then incubated at $37^{\circ} \mathrm{C}$ for $24 \mathrm{~h}$. The following antibiotic disks (oxoid) were used: Nalidixic acid $(30 \mu \mathrm{g})$, streptomycin $(25 \mu \mathrm{g})$, chloramphenicol $(50 \mu \mathrm{g})$, ampicillin $(25 \mu \mathrm{g})$, and tetracycline $(30 \mu \mathrm{g})$. After incubation, antibiotic resistance was assessed by measuring the diameter of the clear zone around the disks, in millimeters. This assay was performed in triplicate.

\subsubsection{Antibacterial activity assay}

2.5.4.1. Disk diffusion method

The isolate was grown in MRS broth (HiMedia, M369) at $37^{\circ} \mathrm{C}$ for 24 h. The optical density of the culture was then adjusted to $\operatorname{OD} 600=0.1$. Escherichia coli (ATCC 25922) and Staphylococcus aureus (ATCC 29213) were used as indicator strains and were grown in nutrient broth (Acumedia, 7146) for $48 \mathrm{~h}$. The optical density of each culture was adjusted to $\mathrm{OD} 600=0.1$. The indicator strains were then spread onto nutrient agar (Acumedia, 7145). Paper disks were then impregnated with the culture of isolate and placed onto the nutrient agar previously prepared. Ampicillin disk (oxoid - $25 \mu \mathrm{g}$ ) was used as positive control, and sterile MRS broth was used as negative control. The plates were then incubated at $37^{\circ} \mathrm{C}$ for $24 \mathrm{~h}$. This assay was performed in triplicate. The antibacterial activity was calculated as follows:

Antibacterial activity $=$ Diameter of inhibition zone - Diameter of paper disk

\subsubsection{Agar spot method}

The isolate was grown in MRS broth (HiMedia, M369) for $24 \mathrm{~h}$ at $37^{\circ} \mathrm{C}$. The optical density of the broth culture was then adjusted to OD600 $=0.1 .2 \mu 1$ of the culture broth was inoculated onto nutrient agar (Acumedia, 7145). The plates were allowed to dry at room temperature for half an hour and were then incubated at $37^{\circ} \mathrm{C}$ for $18 \mathrm{~h}$. Chloramphenicol $(10 \mathrm{mg} / \mathrm{ml})$ was spotted on the plates to act as a positive control. E. coli (ATCC 25922) and S. aureus (ATCC 29213) were used as indicator strains and were grown in nutrient broth (Acumedia, 7146) for $24 \mathrm{~h}$. The optical density of each culture tube was then adjusted to OD600 $=0.1$. Afterward, a set of previously prepared plates were overlaid with a layer $(7 \mathrm{ml})$ of soft nutrient agar supplemented with $1 \mathrm{ml}$ of $E$. coli culture broth and the other set of plates were overlaid with a layer $(7 \mathrm{ml})$ of soft nutrient agar supplemented with $1 \mathrm{ml}$ of $S$. aureus (ATCC 29213) culture broth. The soft media were then allowed to set and the plates were incubated at $37^{\circ} \mathrm{C}$ for $48 \mathrm{~h}$. Antibacterial activity was assessed by measuring the diameter of clear zones in millimeters. This assay was performed in duplicate.

\subsubsection{Lactic acid production assay}

This assay is a modified method described by Fortina et al. [9]. The isolate was grown in MRS broth (HiMedia, M369) at $37^{\circ} \mathrm{C}$ for $24 \mathrm{~h}$. The optical density of the tube was then adjusted to OD600 $=0.1$. $3 \mathrm{ml}$ of the broth culture was inoculated in $30 \mathrm{ml}$ of MRS broth supplemented with $4.5 \mathrm{ml}$ of $1 \%$ glucose ( $\mathrm{pH} 5.5)$. The flask was then incubated in a temperature controlled shaker at $37^{\circ} \mathrm{C}$ for $72 \mathrm{~h} .10 \mathrm{ml}$ of the culture broth was then transferred into a conical flask. $1 \mathrm{ml}$ of phenolphthalein indicator $(0.5 \%$ in $5 \%$ ethanol $)$ was added to the flask. This mixture was titrated against $1 \mathrm{M} \mathrm{NaOH}$. The titratable acidity was calculated as lactic acid \% W/V. Each milliliter of $1 \mathrm{~N} \mathrm{NaOH}$ is equivalent to $90.08 \mathrm{mg}$ of lactic acid [10]. This assay was performed in duplicate.

\subsubsection{Hydrophobicity assay: Microbial adhesion to hydrocarbon} This assay is a modified protocol proposed by Nwanyanwu and $\mathrm{Abu}$ [11]. The isolate was inoculated in $5 \mathrm{ml}$ of MRS broth (HiMedia, M369) and incubated at $37^{\circ} \mathrm{C}$ for $24 \mathrm{~h}$. The broth was then centrifuged at $3000 \mathrm{rpm}$ for $10 \mathrm{~min}$ to pellet the cells. The pellet was then washed and suspended in $2.5 \mathrm{ml}$ of Ringer's solution $(6.5 \mathrm{~g} \mathrm{NaCl}, 0.42 \mathrm{~g} \mathrm{KCl}$, $0.25 \mathrm{~g} \mathrm{CaCl}_{2}, 0.2 \mathrm{~g} \mathrm{NaHCO}_{3}$, and $1000 \mathrm{ml}$ of distilled water). An initial absorbance was read at $600 \mathrm{~nm}$. $500 \mu \mathrm{l}$ of xylene was then added and the tube was incubated at $44^{\circ} \mathrm{C}$ for $10 \mathrm{~min}$. The content of the tube was then vortexed for $1 \mathrm{~min}$ and the two phases were allowed to separate for $1 \mathrm{~h}$. Afterward, the absorbance of the lower aqueous phase (final absorbance) was read at $600 \mathrm{~nm}$. The percentage of hydrophobicity was calculated using the following equation:

$\%$ Hydrophobicity $=([$ Initial absorbance - Final absorbance $] \times 100]$

$\div$ Initial absorbance

This assay was performed in triplicate.

\subsection{Molecular Characterization}

\subsubsection{DNA extraction}

Four DNA extraction protocols were performed with the six isolates, respectively. They are as follows:

1. Protocol A: Method described by Cheng and Jiang [12]

2. Protocol B: Boiling Method described by Abdulla [13]

3. Protocol C: Method described by Moore et al. [14]

4. Protocol D: Method described by De et al. [15].

\subsubsection{Polymerase chain reaction (PCR) amplification}

16S rRNA gene was targeted for the PCR amplification. The following primers were used: Forward - 27F: 5'- AGA GTT TGA TCM TGG CTC AG - 3' and reverse - 1492R: 5'- CGG TTA CCT TGT TAC GAC TT- 3'. Each PCR reaction tube contained $2.5 \mu 1$ Dream Taq buffer (Thermo Scientific ${ }^{\mathrm{TM}}$ B65), $0.2 \mu 1$ Dream Taq (Thermo Scientific ${ }^{\mathrm{TM}}$ EP1701), $2 \mu \mathrm{l}$ of each nucleoside triphosphates, $1 \mu \mathrm{l}$ of forward primer, $1 \mu 1$ of reverse primer, $16.3 \mu \mathrm{l}$ of Millipore water, and $2 \mu \mathrm{l}$ of DNA template.

The PCR conditions were as follows an initial denaturation step at $94^{\circ} \mathrm{C}$ for $3 \mathrm{~min}$, followed by 30 cycles of denaturation at $95^{\circ} \mathrm{C}$ for $1 \mathrm{~min}$, annealing at $55^{\circ} \mathrm{C}$ for $1 \mathrm{~min}$ and extension at $72^{\circ} \mathrm{C}$ for $1 \mathrm{~min}$, and ending with a final extension at $72^{\circ} \mathrm{C}$ for $10 \mathrm{~min}$. To visualize the amplicons, a $1.5 \%$ agarose gel was run.

\subsubsection{DNA sequencing and sequence analysis}

$18 \mu \mathrm{l}$ of each PCR products were sent to Xcelris Labs Limited (India) for DNA purification and DNA sequencing. The sequences obtained were first processed with Bioedit and MEGA 7 software. Sequence analysis then followed using the BLAST algorithm. 


\subsection{Heavy Metal Tolerance Assays}

\subsubsection{Determination of minimum inhibitory concentration (MIC)}

This qualitative assay was done as a preliminary test to assess heavy metal tolerance of the specimens. The isolate was grown in MRS broth (HiMedia, M369), without heavy metals at $37^{\circ} \mathrm{C}$ for $24 \mathrm{~h}$. After incubation, the optical density of the broth culture was adjusted to OD600 $=0.1$ using a light spectrophotometer (JENWAY, 7305). A loopful of the broth culture was then aseptically streaked onto MRS agar (HiMedia, M641) supplemented with different heavy metals $(\mathrm{Hg}, \mathrm{Cr}, \mathrm{Cd}$, and $\mathrm{Pb})$, respectively, at different concentration $(10,20,30,40$, and $50 \mathrm{ppm})$. The plates were then incubated at $37^{\circ} \mathrm{C}$ for $48 \mathrm{~h}$. Single colonies or trace of growth was ignored. The lowest concentration of heavy metals that caused growth inhibition was recorded as the MIC. This assay was performed in triplicate.

\subsubsection{Heavy metal analysis by atomic absorption spectroscopy}

The isolate was grown in $10 \mathrm{ml}$ of MRS broth (HiMedia, M369) for $24 \mathrm{~h}$ at $37^{\circ} \mathrm{C}$. The optical density of the culture broth was adjusted to $\mathrm{OD} 600=1.1 \mathrm{ml}$ of the bacterial suspension was then inoculated in MRS broth supplemented with $10 \mathrm{ppm}$ of the heavy metals $(\mathrm{Hg}$, $\mathrm{Cd}, \mathrm{Cr}$, and $\mathrm{Pb}$ ), respectively. The suspension was then incubated at $37^{\circ} \mathrm{C}$ for $72 \mathrm{~h}$. The broth was then centrifuged at $3000 \mathrm{rpm}$ for $20 \mathrm{~min}$. The supernatant was used for the analysis of heavy metals removal by flame atomic absorption spectroscopy (for $\mathrm{Cd}, \mathrm{Cr}$, and $\mathrm{Pb}$ ) and cold vapor method (for $\mathrm{Hg}$ ). This assay was performed in triplicate. The heavy metal removal efficiency was calculated as percentage removal using the equation below:

$\%$ Removal $=($ Decrease in $\mathrm{HM}$ concentration $\div$ Initial $\mathrm{HM}$ concentration) $\times 100$

Where, HM represents heavy metal.

\subsection{Statistical Analysis}

All the raw data obtained during this study were processed and statistically analyzed. One-way ANOVA, two-sample t-test or Tukey's grouping tests were performed using Minitab Express software.

\section{RESULTS AND DISCUSSION}

By assessing the morphology of the six isolates on MRS medium, it was observed that isolate $\mathrm{BT} 1, \mathrm{BT} 2, \mathrm{MC} 1$, and $\mathrm{MC} 2$ shared similar colony characteristics. On the other hand, distinct colony morphologies were observed with SM1 and SM2 isolates. Microscopic characterization revealed that isolate $\mathrm{BT} 1$ and $\mathrm{BT} 2$ were cocci in shape, $\mathrm{MC} 1$ and MC2 were ovoid, and SM1 and SM2 were rod-shaped. In addition, all the isolates were Gram-positive, nonfastidious, nonspore-forming, noncapsulated, and nonmotile. The results of the various biochemical tests are presented in Table 2.

More than $50 \%$ of each isolate were able to survive in acidic conditions $(\mathrm{pH} 3)$ as shown in Fig. 1. MC1 isolate showed the highest level of tolerance $(86.15 \% \pm 7.944 \%)$, whereas isolate SM2 had the lowest mean survival percentage $(63.74 \% \pm 10.89 \%)$. Over $80 \%$ of the Enterococcus species (BT1, BT2, MC1, and MC2) and 60\% of the Bacillus isolates (SM1 and SM2) were able to survive at $\mathrm{pH} 3$ after $24 \mathrm{~h}$.

These results are supported by previous studies performed that demonstrated some strains of Bacillus [16], Enterococcus faecium [17], and other Enterococcus species [18] were able to survive in an environment of $\mathrm{pH}$ 3. Many bacterial species have the ability
Table 2: Biochemical characterization of the six isolates.

\begin{tabular}{lcccccc} 
& \multicolumn{7}{c}{ Isolates } \\
\cline { 2 - 6 } Tests & BT1 & BT2 & MC1 & MC2 & SM1 & SM2 \\
Biochemical tests & & & & & & \\
Catalase test & - & - & - & - & - & - \\
Oxidase test & - & - & - & - & - & - \\
Starch digestion test & - & - & - & - & - & - \\
Growth on Bile & + & + & + & + & - & - \\
esculin azide agar & & & & & & \\
Methyl red test & + & + & + & + & + & + \\
Voges-Proskauer test & - & - & - & - & - & - \\
Sugar fermentation & & & & & & \\
tests & & & & & & \\
Glucose & + & + & + & + & + & + \\
Lactose & + & + & + & + & + & - \\
Maltose & + & + & + & + & + & - \\
Fructose & + & + & + & + & + & + \\
\hline
\end{tabular}

+ : Positive, -: Negative

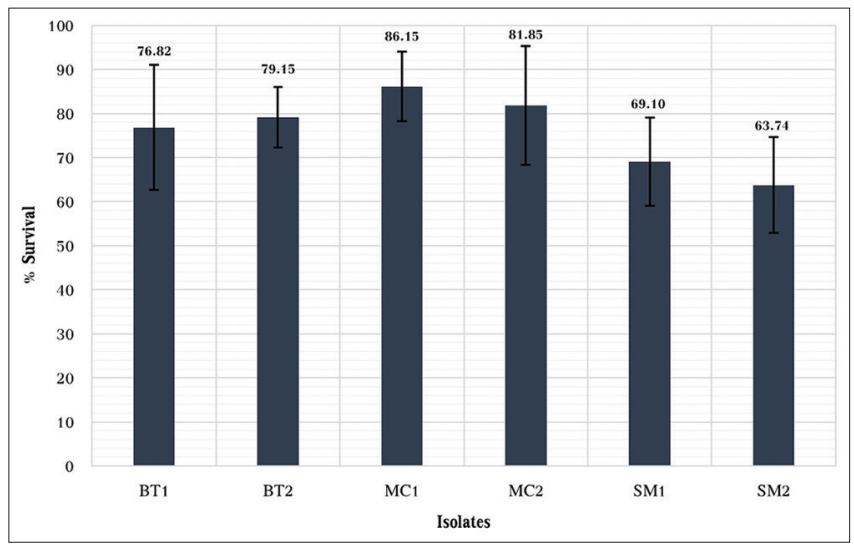

Fig. 1: Bar chart is illustrating percentage survival of the isolates in acidic conditions. The error bars on the bar chart indicate the standard deviation and the data labels represent the mean percentage survival.

to grow in acidic conditions due to different types of acid resistance mechanisms. Enterococcus and Bacillus are able to tolerate such acidic conditions due to intrinsic mechanisms.

$\mathrm{BT} 1, \mathrm{BT} 2, \mathrm{MC} 1$, and $\mathrm{MC} 2$ were tolerant to all the different concentrations of bile salts (1000-4000 ppm) (Table 3). Nevertheless, SM1 and SM2 showed poor growth on the MRS agar medium supplemented with $3000 \mathrm{ppm}$ and $4000 \mathrm{ppm}$ of bile salts. A decrease in colony size was also observed with these two bacteria. The Enterococcus species showed a higher level of bile tolerance compared to SM1 and SM2 isolates. The results obtained during this protocol were in accordance to the previous studies performed [17,19-21]. Not much work has been reported concerning bile tolerance within Bacillus acidiproducens. However, specific strains of Bacillus are known to tolerate up to $0.5 \%$ of bile salts in media [22]. Specific bacteria tolerate bile through intrinsic mechanisms. Several Enterococcus species are speculated to have the ability to tolerate bile through a process known as deconjugation. This process occurs mainly in the small intestine and involves the action of bile salt hydrolase enzymes. These enzymes are both present in Gram-negative and Gram-positive bacteria. 
Table 3: Bile tolerance assay results.

\begin{tabular}{lcccc} 
Isolate & \multicolumn{4}{c}{ Bile concentration (ppm) } \\
\cline { 2 - 5 } & $\mathbf{1 0 0 0}$ & $\mathbf{2 0 0 0}$ & $\mathbf{3 0 0 0}$ & $\mathbf{4 0 0 0}$ \\
BT1 & ++ & ++ & ++ & ++ \\
BT2 & ++ & ++ & ++ & ++ \\
MC1 & ++ & ++ & ++ & ++ \\
MC2 & ++ & ++ & ++ & ++ \\
SM1 & ++ & ++ & + & + \\
SM2 & ++ & ++ & + & + \\
\hline
\end{tabular}

++: Good growth, +: Poor growth, -: No growth

The six isolates were resistant to $30 \mu \mathrm{g}$ of nalidixic acid. Previous studies have shown that 105 strains of Enterococcus and certain specific strains of Bacillus are resistant to this antibiotic [23].

In addition, it was observed that streptomycin $(25 \mu \mathrm{g})$ did have an inhibitory effect on the growth of BT2, MC2, and SM1 isolates, with a respective inhibition zone of $0.67 \pm 1.155,2.00 \pm 2.000$, and $3.33 \pm$ $3.055 \mathrm{~mm}$. However, no inhibition zone was obtained against isolates BT1, MC1, and SM2.

All the isolates showed susceptibility to tetracycline $(30 \mu \mathrm{g})$ and chloramphenicol $(50 \mu \mathrm{g})$. Chloramphenicol and tetracycline are considered as macrolides and aminoglycosides, respectively. These molecules mainly bind to ribosomes and alter their function. Tetracycline had the highest inhibitory effect on all the isolates. In turn, the highest level of tetracycline activity was observed with isolate SM1 with an inhibition zone of $30.00 \pm 2.000 \mathrm{~mm}$, and the lowest activity was observed with $\mathrm{MC1}(15.33 \pm 6.429 \mathrm{~mm})$. Similarly, chloramphenicol had a highest inhibitory effect on SM1 (20.00 \pm $4.000 \mathrm{~mm}$ ), and $\mathrm{MC1}$ showed the highest resistance level with an inhibition zone of $10.67 \pm 4.163 \mathrm{~mm}$.

Moreover, all the isolates were susceptible to ampicillin $(25 \mu \mathrm{g})$ with inhibition zones ranging from 12 to $26 \mathrm{~mm}$. The results gathered during the experiment were in concordance with other studies [24]. However, most Enterococci are said to be resistant to ampicillin [25]. It was not the case in this study. BT1, BT2, MC1, and MC2 were susceptible to $25 \mu \mathrm{g}$ of ampicillin.

In general, SM1 was the most susceptible bacteria against all the antibiotics, except nalidixic acid, whereas MC1 showed better resistance against the antibiotics compared to the five other bacteria. The results of one-way ANOVA analysis showed that tetracycline had different effects on the isolates $(P<0.05)$. Grouping by Tukey's method also demonstrated that tetracycline had a greater inhibitory effect on SM1 compared to the other isolates. On the other hand, chloramphenicol, streptomycin, and ampicillin did not have contrasting effects on the growth of the bacteria separately $(P>0.05)$.

Two antibacterial activity assays were performed. The six bacterial strains did not express any antibacterial activity against both $E$. coli (ATCC 25922) and S. aureus (ATCC 29213) with both protocols. During a previous study performed, it was demonstrated that several Bacillus species did not have any inhibitory effect on S. aureus [26]. This is in accordance with the results obtained with isolates SM1 and SM2 against the same indicator strain. On the other hand, another study demonstrated that while using the cell-free supernatant method, Bacillus species had an inhibitory effect on the growth of $S$. aureus [27]. It has been also reported that Bacillus subtilis [28] and E. faecium [29] inhibited the growth of E. coli. Furthermore, the ultrafiltered concentrate of the cell-free culture of $B$. subtilis showed inhibitory effects against $E$. coli [30]. In both protocols, the culture broth was taken to test antibacterial activity. Cell-free supernatant methods could be used for more accurate results.

BT2 produced the highest amount of lactic acid $(54.27 \pm 6.053 \mathrm{mg} /$ $\mathrm{ml}$ ), and in contrast, SM1 produced $33.78 \pm 1.911 \mathrm{mg}$ of lactic acid per $\mathrm{ml}$ which was the lowest amount recorded. In addition, lactic acid production from the other isolates ranged from 45 to $50 \mathrm{mg} / \mathrm{ml}$. The six isolates produced approximately similar amounts of lactic acid $(P$ $>0.05)$. A comparative study was performed with different species of Enterococcus to determine the ones producing a higher amount of lactic acid. E. faecium and Enterococcus faecalis produced greater amount of lactic acid [31]. It has also been reported that $B$. acidiproducens also produce lactic acid [32].

Cell surface hydrophobicity was performed using xylene as solvent. The isolates demonstrated a moderate level of cell surface hydrophobicity $(>30 \%)$. The highest percentage of cell surface hydrophobicity was recorded with isolate MC2 $(33.38 \% \pm 4.700 \%)$. MC1, in turn, showed the lowest level of cell surface hydrophobicity $(10.79 \% \pm 8.046 \%)$. The other specimens (BT1, BT2, SM1, and SM2) had cell surface hydrophobicity ranging from 15 to $27.35 \%$. According to one-way ANOVA analysis, the difference in means was not significant $(P>0.05)$. Cell surface hydrophobicity is essential to the bacteria for adhesion to hydrocarbons [33]. This property could be useful in many beneficial processes such as degradation of hydrocarbon pollutants [34]. Certain Gram-positive bacteria have the ability to fluctuate their cell surface hydrophobicity depending on their surrounding environment [35]. Cell surface hydrophobicity is somehow related to different proteins and other biological molecules, such as lipoteichoic acid, found with the cell wall and cell membranes of bacteria.

Fig. 2 illustrates the electrophoresis gel images obtained with the four protocols. Protocol A was successful for only two isolates, namely, SM1 and SM2 and their respective DNA purity obtained, $1.72 \pm 0.130$ and $1.84 \pm 0.145$, was rather of high quality. A two-sample t-test was performed using the results obtained with Protocol A. The analysis revealed that there were no significant differences between the mean DNA purity $(P>0.05)$. DNA extraction of all the isolates was successful with Protocol C and Protocol D. It was found that Protocol D yielded DNA of better purity, ranging from 1.63 to 1.82 compared to Protocol C which extracted DNA of purity varying from 1.19 to 1.78 .

The highest amount of DNA extracted from isolate BT1, BT2, and SM1 was obtained with Protocol C. Still, highest quantity of DNA extracted from specimen MC1 and MC2 was observed when using Protocol D, and Protocol A yielded the highest amount of DNA from isolate SM2. Statistical analysis performed (two-sample t-test for Protocol A and one-way ANOVA for Protocol C and D, respectively) concluded that first, there were no statistical differences between the mean DNA yield of SM1 and SM2 obtained with Protocol A $(P>0.05)$ and that there were no significant differences between the mean DNA yields of all the isolates, obtained with Protocol C and Protocol D, respectively $(P>0.05)$.

Fig. 3 illustrates the amplified DNA on an electrophoresis gel. The length of the six amplicons was about 1500 base pairs. DNA sequences were analyzed using the BLAST algorithm. BT2 was characterized as being relatively close to E. faecium. Furthermore, SM1 and SM2 shared $99 \%$ homology with the bacteria B. acidiproducens. However, some morphological and biochemical characteristics of this bacterium do not coincide with the results obtained with both isolates. This 
may have been due to various stresses imposed on the isolates such as temperature shocks or lack of specific nutrients within the media. On the other hand, BT1 shared 99\% homology with Enterococcus hirae, Enterococcus durans, Enterococcus thailandicus, E. faecium, and Enterococcus lactis. The sequences expressing 99\% homology with BT1 were retrieved from the NCBI database. They were then aligned with the BT1 sequence using MEGA 7 software and ClustalW alignment. A neighbor-joining tree was generated to determine the closest relative of the isolate. Unfortunately, BT1 was considered as the outgroup in the tree (Fig. 4). 16S rRNA sequences of bacteria found in the order of Lactobacillales were therefore retrieved from the NCBI database to generate a maximum parsimony tree (Fig. 5). Species of Bifidobacterium were used as outgroup. The phylogeny was tested using the bootstrap method. After analysis, BT1 is said to be more closely related to E. faecium and E. lactis. Similar analysis was performed with isolate $\mathrm{MC1}$ who shared $99 \%$ homology with the five Enterococcus species, namely, E. faecium, E. lactis, E. durans, E. thailandicus, and E. hirae. A most parsimonious tree was generated (Fig. 6) with the aligned sequences and using Enterococcus mundtii and Enterococcus sulfureus as outgroup. The tree revealed that the $\mathrm{MC1}$ is closely related to E. hirae compared to the other species. MC2 shared homology (99\%) with six species of Enterococcus. A most parsimonious tree generated was generated. The tree revealed that its closest relative was $E$. hirae (Fig. 7). One of the main drawbacks of
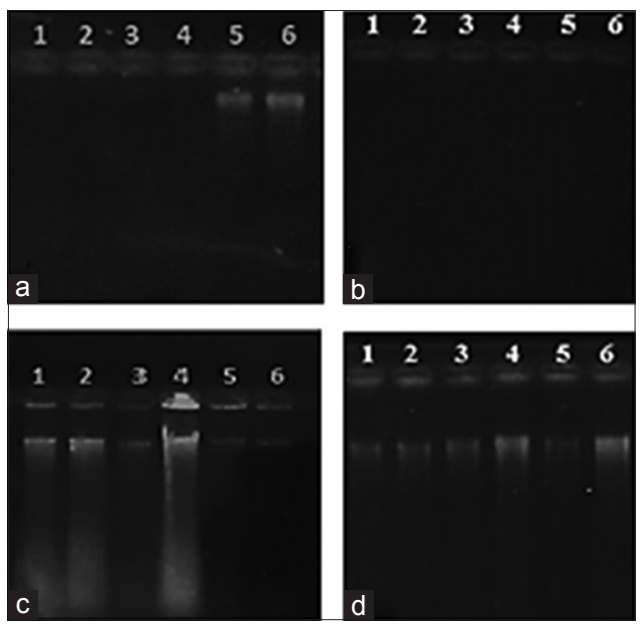

Fig. 2: Electrophoresis gel images obtained with the protocol described by Cheng and Jiang (2006) (a), Abdulla (2014) (b), Moore et al. (2004) (c), and De et al. (2011) (d).

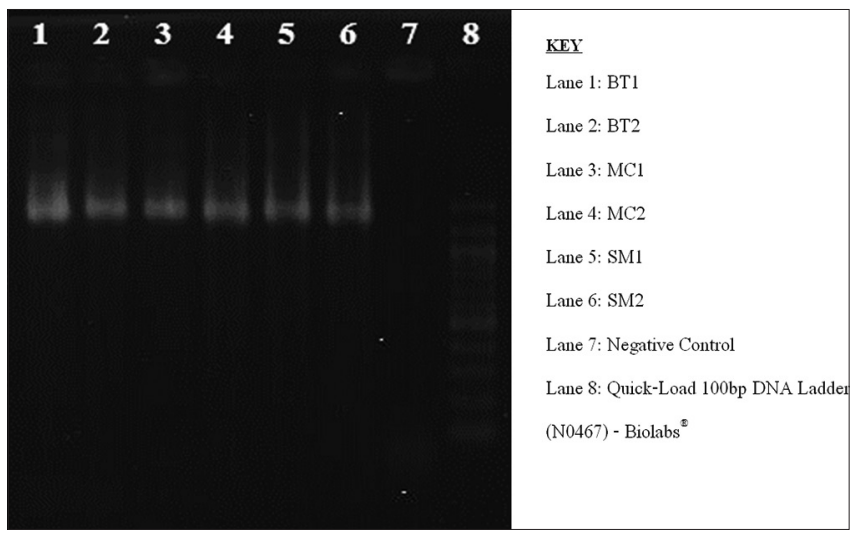

Fig. 3: Gel electropherogram of amplicons.
16S rRNA sequencing is that, in some cases, it fails to identify specific species within a genus. The 16S rRNA gene is well conserved and shows little diversity among bacteria of the same genus. The following case happened while analyzing the DNA sequences of BT1, MC1, and $\mathrm{MC} 2$ isolates. The genus of the isolates was identified as being part of the Enterococcus genus. Neither the species nor the strain could be differentiated.

Determination of the MIC of heavy metals was evaluated as a preliminary test to identify the metal tolerant specimens. Table 4 summarizes the MIC of the four heavy metals tested against the growth of the isolates. Bacteria that showed no growth on MRS medium supplemented with $10 \mathrm{ppm}$ of any heavy metals were considered as intolerant. Table 5 summarizes the deductions made after the test. The outcome of the preliminary heavy metal tolerance test revealed that the Enterococci species, BT1 and BT2, were tolerant to the four heavy metals tested in this study. They were able to grow in media supplemented with more than $10 \mathrm{ppm}$ of mercuric, $\mathrm{Cd}, \mathrm{Pb}$, and $\mathrm{Cr}$ compounds separately. $\mathrm{MC} 1$ and $\mathrm{MC} 2$, characterized as being closely related to E. hirae, were able to sustain $\mathrm{Pb}, \mathrm{Cr}$, and $\mathrm{Cd}$ in their environment. Moreover, finally, the two $B$. acidiproducens isolate (SM1 and SM2) mainly grew in medium containing only $\mathrm{Cr}$ or $\mathrm{Pb}$. They were highly susceptible to the other metal tested in this study. Not much information is available on the metal resistance ability of $B$. acidiproducens. Moreover, E. hirae is mainly known to possess $\mathrm{Cu}$ resistance through intrinsic mechanisms or encoded on genes or plasmids. Resistance to other heavy metals has not been fully reported. Advanced molecular techniques should be used to identify the specific mechanism involved in heavy metal tolerance and resistance within each isolate. In general, bacteria have adapted to toxic metals in their surrounding environment. There are five main mechanisms of heavy metal resistance within bacteria, namely, efflux mechanisms, extracellular barriers, extracellular sequestration, intracellular sequestration, and reduction of metal ions. In addition, some bacterial strains have specific heavy metal tolerant or resistant genes encoded either in their genomes or on plasmids [36].

BT1 and BT2 demonstrated poor Hg removal abilities with a mean ranging from $0.75 \%$ to $1.42 \%$ (Table 6 ). Their differences in mean percentage removal were not significant $(P>0.05)$. They both have been characterized as being a part of the Enterococcus genus. A molecular study reported the $\mathrm{Hg}$ resistance ability of several Enterococcus species.

Table 4: MIC of the different heavy metals for the growth of isolates.

\begin{tabular}{lcccccc} 
Heavy metals & \multicolumn{7}{c}{ Isolates } \\
\cline { 2 - 7 } & BT1 & BT2 & MC1 & MC2 & SM1 & SM2 \\
Mercury & 10 & 40 & $<10$ & $<10$ & $<10$ & $<10$ \\
Chromium & 40 & 30 & 40 & 40 & 40 & 40 \\
Cadmium & 10 & 30 & 40 & 40 & $<10$ & $<10$ \\
Lead & 30 & 40 & 40 & 30 & 40 & 40 \\
\hline
\end{tabular}

MIC: Minimum inhibitory concentration

Table 5: Heavy metal tolerant isolates.

\begin{tabular}{lcccccc} 
Heavy metals & \multicolumn{7}{c}{ Isolates } \\
\cline { 2 - 7 } & BT1 & BT2 & MC1 & MC2 & SM1 & SM2 \\
Mercury & + & + & - & - & - & - \\
Chromium & + & + & + & + & + & + \\
Cadmium & + & + & + & + & - & - \\
Lead & + & + & + & + & + & + \\
\hline
\end{tabular}

+: Tolerant, -: Intolerant 


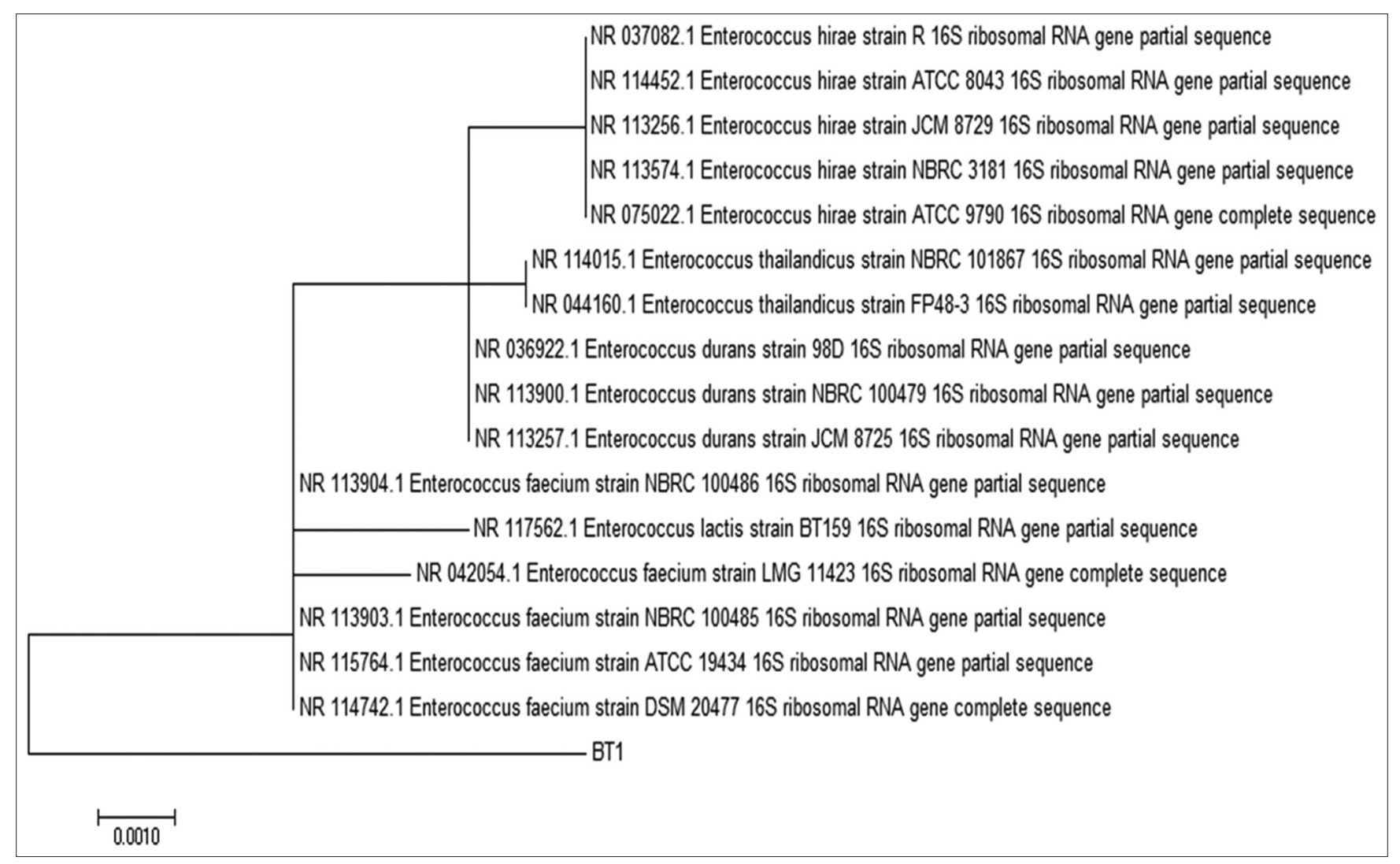

Fig. 4: Neighbor-joining tree generated after alignment of BT1 sequence and the retrieved sequences.

Table 6: Heavy metals removal efficiency of the six isolates calculated as $\%$ removal.

\begin{tabular}{lcccc} 
Isolate & \multicolumn{4}{c}{ Heavy metal analysis (\% removal) } \\
\cline { 2 - 5 } & Mercury & Cadmium & Chromium & Lead \\
BT1 & $0.75 \pm 0.601$ & $45.57 \pm 13.918$ & $39.11 \pm 7.114$ & $35.16 \pm 3.571^{\mathrm{a}, \mathrm{b}}$ \\
$\mathrm{BT} 2$ & $1.42 \pm 0.529$ & $33.82 \pm 10.891$ & $36.77 \pm 5.503$ & $36.79 \pm 3.644^{\mathrm{a}, \mathrm{b}}$ \\
MC1 & N/A & $46.19 \pm 7.651$ & $41.13 \pm 6.699$ & $43.00 \pm 0.776^{\mathrm{a}}$ \\
MC2 & N/A & $31.55 \pm 2.955$ & $33.78 \pm 4.082$ & $38.90 \pm 3.368^{\mathrm{a}, \mathrm{b}}$ \\
SM1 & N/A & N/A & $39.93 \pm 13.498$ & $32.33 \pm 4.522^{\mathrm{b}}$ \\
SM2 & N/A & N/A & $43.06 \pm 7.991$ & $34.44 \pm 1.021^{\mathrm{a}, \mathrm{b}}$ \\
\hline
\end{tabular}

Data is expressed as mean \pm standard deviation

Moreover, researchers have discussed and compared the similarity between $\mathrm{Hg}$ resistance genes within Staphylococcus and Enterococcus species in the same study. They have stated the involvement of specific enzymes in $\mathrm{Hg}$ resistance of these microorganisms [37].

The Cr metal removal efficiency was calculated as percentage removal, and the results are shown in Table 6. The results obtained revealed that all the isolates were able to remove $\mathrm{Cr}$ from the broth medium. On average, SM2 had the ability to remove the highest amount of $\mathrm{Cr}$ $(43.06 \% \pm 7.991 \%)$. Moreover, the $\mathrm{Cr}$ removal efficiency of the five other bacterial species ranged from $33.78 \%$ to $41.13 \%$. The differences between the mean percentage removals of the six isolates were not significant $(P>0.05)$. The tolerant characteristics of Enterococcus casseliflavus have been previously evaluated by researchers, and the outcome of this study revealed that the bacteria were tolerant to a $\mathrm{Cr}$ level of $800 \mu \mathrm{g} / \mathrm{ml}$ [38]. Moreover, it has been reported that some Bacillus species are able to tolerate up to $100 \mathrm{mg} / \mathrm{ml}$ of $\mathrm{Cr}$ within their culture media [39]. In another study, Bacillus circulans MN1 tolerated a Cr concentration of $1110 \mathrm{mg} / \mathrm{L}$ [40]. These are in concordance with the results obtained in this study. There are two main mechanisms involved in Cr resistance within bacteria, namely, biotransformation of $\mathrm{Cr}$ (VI) into a less toxic form ( $\mathrm{Cr}[\mathrm{III}])$, under specific conditions, and biosorption where the bacteria absorb the pollutant in its biomass [41]. In specific cases, hexavalent $\mathrm{Cr}$ serves as the terminal electron acceptor in the respiratory process of certain bacteria. This mechanism will indeed detoxify $\mathrm{Cr}$ (VI) while providing energy for bacterial cell growth [42].

$\mathrm{Cd}$ analysis by flame AAS was performed with the $\mathrm{Cd}$ tolerant isolates, namely, BT1, BT2, MC1, and MC2. The raw data obtained were processed and are tabulated in Table $6 . \mathrm{MC} 1$ was able to remove the highest amount of $\mathrm{Cd}$ from the culture medium $(46.19 \% \pm 7.651 \%)$. It was closely followed by BT1 which showed good removal abilities by eliminating $45.57 \% \pm 13.918 \%$ of Cd found in the MRS broth. The two other isolates, BT2 and MC2, were also capable of removing 33.82\% $\pm 10.891 \%$ and $31.55 \% \pm 2.955 \%$ of $\mathrm{Cd}$, respectively. The differences between the mean removals of $\mathrm{Cd}$ by the six specimens were not significant $(P>0.05)$. The Enterococci (BT1, BT2, MC1, and MC2) were able to tolerate Cd compounds within their growth medium. In a previous study performed, it was reported that three strains of $E$. faecium were resistant to $\mathrm{Cd}$ sulfate. They were able to grow in the presence of up to $70 \mathrm{mg} / \mathrm{L}$ of $\mathrm{Cd}$ in their environment [43]. Furthermore, E. faecalis exhibit a high level of natural resistance against $\mathrm{Cd}$ in their environment [44]. There are two main genes involved in Cd resistance, namely, cadA and cadC [45]. CadA codes for a Cd efflux ATPase and $c a d C$ are said to be a transcriptional regulatory protein and a repressor of the cad operon [46]. In the presence of Cd ions, the repressor detaches itself from the DNA molecule, thus, allowing the transcription of the operon [47]. 


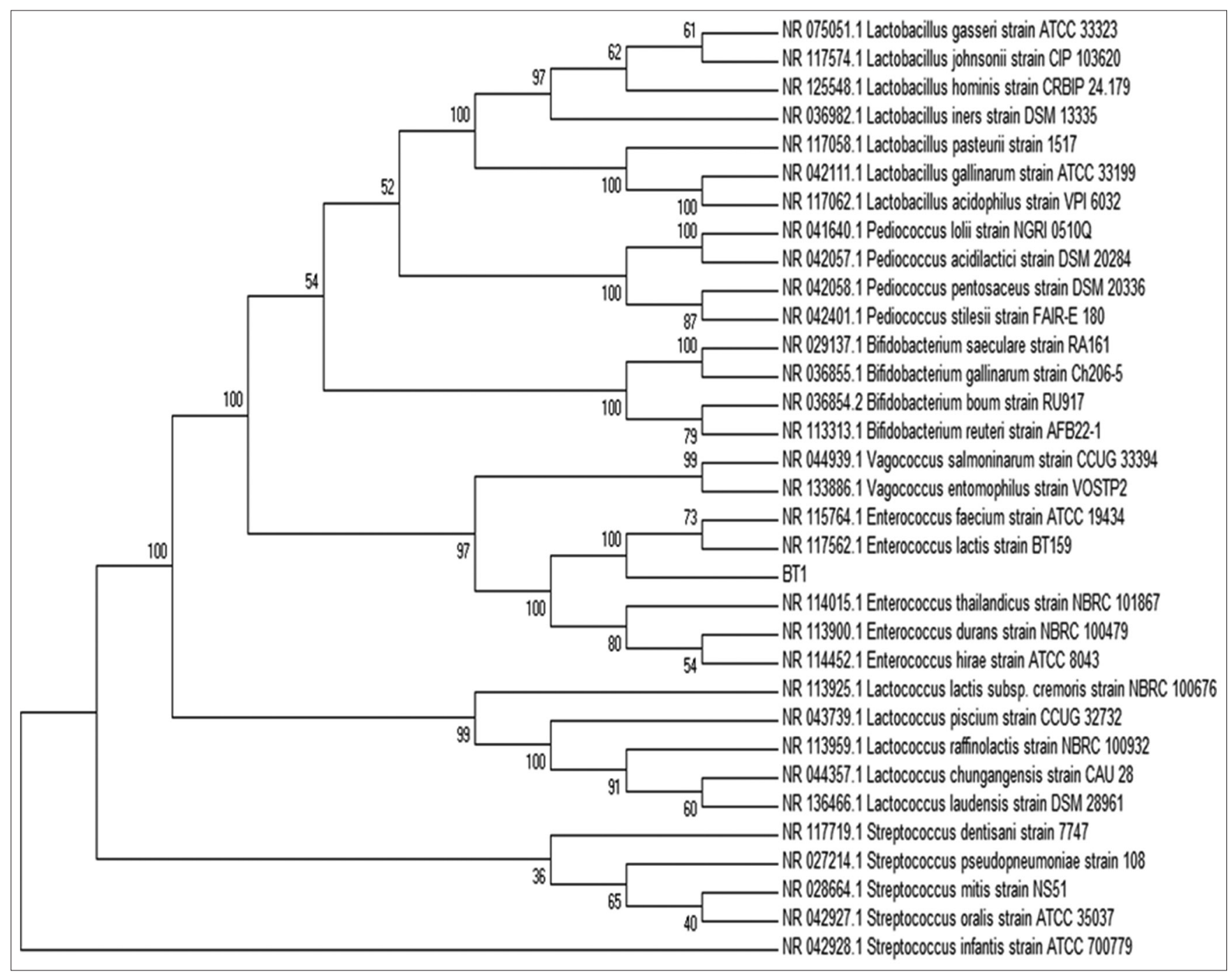

Fig. 5: Most parsimonious tree with bootstrap values for the identification of BT1.

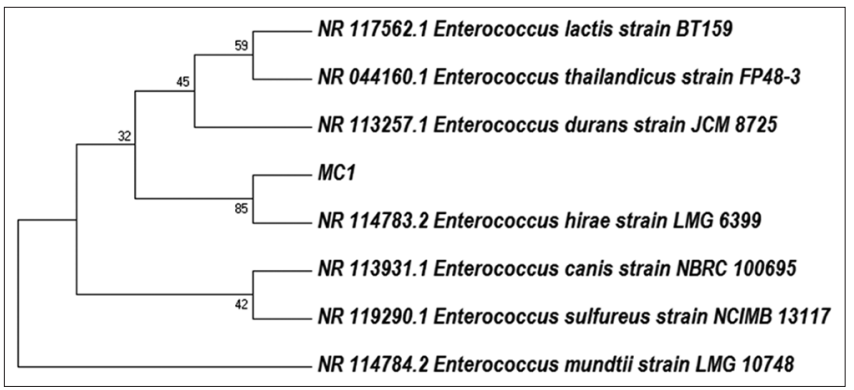

Fig. 6: Most parsimonious tree generated to identify MC1.

All the isolates were able to remove $\mathrm{Pb}$ from MRS broth. Their mean $\mathrm{Pb}$ removal efficiency (\% removal) ranged from $32.33 \%$ to $38.903 \%$. It was observed that MC1 showed the highest level of removal of $\mathrm{Pb}(43.00 \% \pm 0.776 \%)$ (Table 6). Following an analysis of variance, it was found that the differences between the means were significant $(P<0.05)$. Grouping by Tukey's method also confirms the fact that $\mathrm{MC} 1$ removed the highest level of $\mathrm{Pb}$ from the broth medium compared to the other isolates. Studies have shown that several Enterococcus strains were resistant to $\mathrm{Pb}$ compounds within their growth medium [48]. In addition, different Bacillus species have the ability to tolerate and resist this heavy metal [49]. For example, two strains of $B$. subtilis, OSTAM1 and OSTAM2, were able to grow in media containing up to $1000 \mu \mathrm{g} / \mathrm{ml}$ of $\mathrm{Pb}$ [50]. Many mechanisms are used by the bacteria to tolerate or resist $\mathrm{Pb}$ compounds. Limitation of metal movement across the cell wall is one mechanism used by the bacteria to prevent intoxication. The cell wall acts as a barrier against $\mathrm{Pb}$ ions. Especially in Gram-positive bacteria, $\mathrm{Pb}$ will bind to the peptidoglycan layer as well as the teichoic and teichuronic acids found on the cell wall [51]. Furthermore, bacteria may also produce extracellular polymers such as exopolysaccharide to which $\mathrm{Pb}$ will bind, therefore protecting the whole cell from heavy metal contamination [52]. A common mechanism used by Enterococcus and Bacillus species involved the use of P-type ATPase pumps which regulate the movement of metal ions across the cell membrane [53].

\section{CONCLUSION}

Six bacteria were isolated from three different metal polluted soils in Mauritius. Their morphology and biochemical characteristics were assessed by the examination of colony morphology, staining procedures, and biochemical tests. Furthermore, 16S rRNA sequencing and sequence analysis were performed to fully identify the different microorganisms. Four of the isolated bacteria formed part of the Enterococcus family, and the two other isolates were characterized as $B$. acidiproducens. Moreover, these isolates were subjected to 


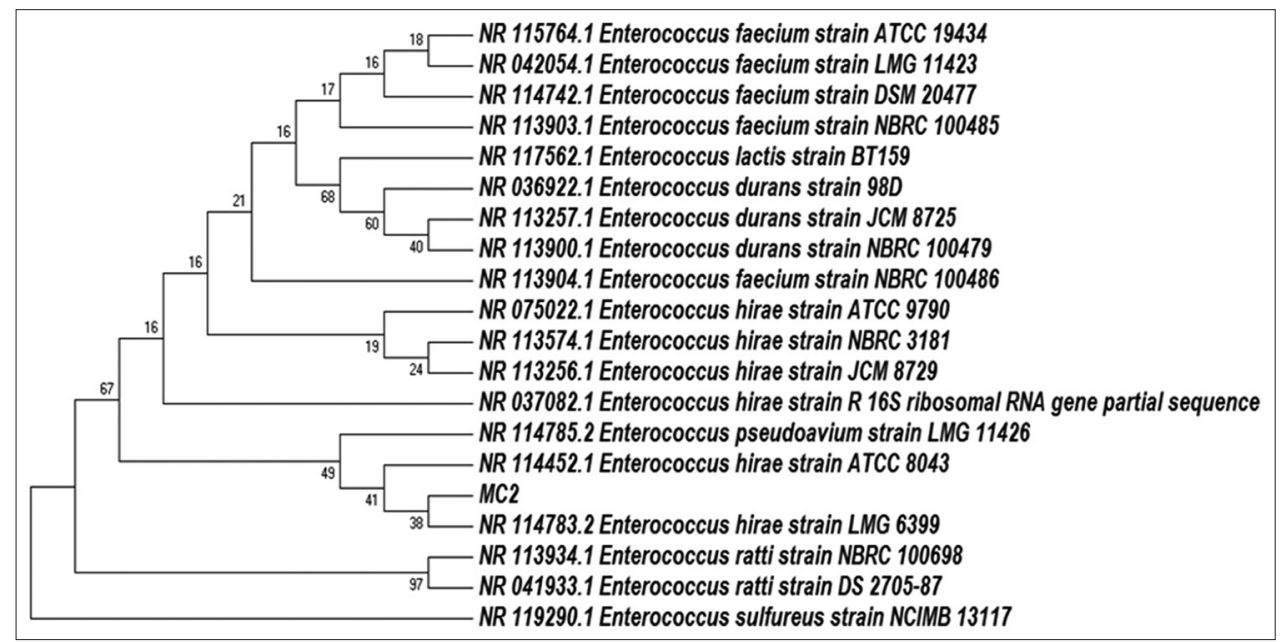

Fig. 7: Most parsimonious tree generated for the identification of MC2.

various assays to assess their probiotic characteristics. All of them were acid and bile tolerant. Furthermore, they were able to produce a considerable amount of lactic acid by metabolizing glucose. Their cell wall surface hydrophobicity was also assessed and was considered as moderately hydrophobic. Similar antibiotic susceptibility profiles were observed during this study. However, none of the isolates exerted any antibacterial activity against the two tested indicator strains.

Moreover, the six bacteria were subjected to several tests to assess their tolerance to different heavy metals at different concentrations. $\mathrm{BT} 1$ and BT2 were able to tolerate $\mathrm{Hg}, \mathrm{Cd}, \mathrm{Pb}$, and $\mathrm{Cr}$. $\mathrm{MC} 1$ and $\mathrm{MC} 2$ isolates could grow in MRS medium supplemented with $\mathrm{Cd}, \mathrm{Pb}$, and $\mathrm{Cr}$. Yet, SM1 and SM2 isolates tolerated only $\mathrm{Pb}$ and $\mathrm{Cr}$. Advanced analysis was then performed using a flame AAS and the cold vapor method to determine the heavy metal removal efficiency of the six bacteria. All the isolates showed reasonable removal efficiencies of the heavy metals. It can be concluded that the bacterial isolates could remediate metal toxicity within a broth culture. Advanced in vitro and in vivo tests should be performed to fully assess the efficiency of the bacteria to remediate heavy metal pollution in nature.

\section{ACKNOWLEDGMENTS}

The authors wish to thank the University of Mauritius for its financial support and the technical staff of the Faculty of Agriculture for their assistance.

\section{REFERENCES}

1. Gadd GM, Griffiths AJ. Microorganisms and heavy metal toxicity. Microb Ecol 1977;4:303-17.

2. Daby D. Coastal pollution and potential biomonitors of metals in mauritius. Water Air Soil Pollut 2006;174:63-91.

3. Ramessur RT, Boodhoo K. Trace metal contamination in Urban sediments in port Louis, mauritius. Environ Ecol Res 2013;1:155-60.

4. Todar K. The Good, the Bad, and the Deadly. $1^{\text {st }}$ ed. Wyoming USA: Opalescent Pool in Yellowstone National Park; 2004.

5. Meriluoto J, Gueimonde M, Haskard CA, Spoof L, Sjövall O, Salminen S. Removal of the cyanobacterial toxin microcystin-LR by human probiotics. Toxicon 2005;46:111-4.

6. Halttunen T, Salminen S, Tahvonen R. Rapid removal of lead and cadmium from water by specific lactic acid bacteria. Int J Food Microbiol 2007;114:30-5.
7. Delcour J, Ferain T, Deghorain M, Palumbo E, Hols P. The biosynthesis and functionality of the cell-wall of lactic acid bacteria. Antonie Van Leeuwenhoek 1999;76:159-84.

8. Arihara K, Ota H, Itoh M, Kondo Y, Sameshima T, Yamanaka H, et al. Lactobacillus acidophilus group lactic acid bacteria applied to meat fermentation. J Food Sci 1998;63:544-7.

9. Fortina MG, Parini C, Rossi P, Manachini PL. Mapping of three plasmids from Lactobacillus helveticus ATCC 15009. Lett Appl Microbiol 1993;17:303-6.

10. Sheeladevi A, Ramanathan N. Lactic acid production using lactic acid bacteria under optimized conditions. Int J Pharm Biol Arch 2012;2:1681-91.

11. Nwanyanwu C, Abu G. Influence of growth media on hydrophobicity of phenol-utilizing bacteria found in petroleum refinery effluent. Int Res J Biol Sci 2013;2:6-10.

12. Cheng H, Jiang N. Extremely rapid extraction of DNA from bacteria and yeasts. Biotechnol Lett 2006;28:55-9.

13. Abdulla A. Optimization of DNA extraction of Lactobacillus spp for identification by tuf B gene-based polymerase chain reaction. J Biol Agric Healthc 2014;4:122-5.

14. Moore E, Arnscheidt A, Kruger A, Strompl C, Mau M. Simplified protocols for the preparation of genomic DNA from bacterial cultures. Mol Microb Ecol Man Second Ed 2004;1:3-18.

15. De S, Kaur G, Roy A, Dogra G, Kaushik R, Yadav P, et al. A simple method for the efficient isolation of genomic DNA from Lactobacilli isolated from traditional Indian fermented milk (dahi). Indian $\mathrm{J}$ Microbiol 2010;50:412-8.

16. Mols M, Abee T. Bacillus cereus responses to acid stress. Environ Microbiol 2011;13:2835-43.

17. Strompfova V, Laukova A. In vitro study on bacteriocin production of enterococci associated with chickens. Anaerobe 2007;13:228-37.

18. Cebeci A, Gurakan C. Properties of potential probiotic Lactobacillus plantarum strains. Food Microbiol 2003;20:511-8.

19. Maldonado NC, de Ruiz CS, Nader-Macias ME. Design of a beneficial product for newborn calves by combining Lactobacilli, minerals, and vitamins. Prep Biochem Biotechnol 2015;46:648-56.

20. Bloch C, Allameh SK, Ringø E, Yusoff FM, Daud HM, Ideris A, et al. Properties of Enterococcus faecalis, a new probiotic bacterium isolated from the intestine of snakehead fish. Afr J Microbiol Res 2014;8:2215-22.

21. Tavakoli M, Hamidi-esfahani Z, Amin M. Characterization of probiotic abilities of Lactobacilli isolated from Iranian Koozeh traditional cheese. Pol J Food Nutr Sci 2017;67:41-8.

22. Adami A, Cavazzoni V. Occurrence of selected bacterial groups in 
the faeces of piglets fed with Bacillus coagulans as probiotic. J Basic Microbiol 1999;39:3-9.

23. Shale K, Malebo N. Quantification and antibiotic susceptibility profiles of Staphylococcus aureus and Bacillus cereus strains isolated from biltong. J Food Saf 2011;31:559-69.

24. Reva ON, Vyunitskaya VA, Reznik SR, Kozachko IA, Smirnov VV. Antibiotic susceptibility as a taxonomic characteristic of the genus Bacillus. Int J Syst Bacteriol 1995;45:409-11.

25. Hallgren A. Antimicrobial susceptibility patterns of enterococci in intensive care units in Sweden evaluated by different MIC breakpoint systems. J Antimicrob Chemother 2001;48:53-62.

26. Yilmaz M, Soran H, Beyatli Y. Antimicrobial activities of some Bacillus spp. strains isolated from the soil. Microbiol Res 2006;161:127-31.

27. Kıvanç SA, Takım M, Kıvanç M, Güllülü G. Bacillus Spp. Isolated from the conjunctiva and their potential antimicrobial activity against other eye pathogens. Afr Health Sci 2014;14:364-71.

28. Fernandes V, Souto-maior AM, André P, De-Arruda IR, Fernando A, Botelho A, et al. Antimicrobial activity of surfactants produced by Bacillus subtilis R14 against multidrug-resistant bacteria. Braz J Microbiol 2007;38:704-8.

29. Zheng W, Zhang Y, Lu HM, Li DT, Zhang ZL, Tang ZX, et al. Antimicrobial activity and safety evaluation of Enterococcus faecium KQ 2.6 isolated from peacock feces. BMC Biotechnol 2015;15:30.

30. Ramachandran R, Chalasani A, Lal R, Roy U. A broad-spectrum antimicrobial activity of Bacillus subtilis RLID 12.1. Sci World J 2014;2014:1-10.

31. Angkau P. Comparative Lactic acid Production Between Enterococcus faecalis and Enterococcus faecium in Hydrolysed Sago Starch. Malaysia: Universiti Malaysia Sarawak; 2013.

32. Jung MY, Kim J, Chang Y. Bacillus acidiproducens sp. nov, vineyard soil isolates that produce lactic acid. Int J Syst Evol Microbiol 2017;59:2226-31.

33. Kaczorek E, Chrzanowski Ł, Pijanowska A, Olszanowski A. Yeast and bacteria cell hydrophobicity and hydrocarbon biodegradation in the presence of natural surfactants: Rhamnolipides and saponins. Bioresour Technol 2008;99:4285-91.

34. Obuekwe C, Al-Jadi Z, Al-Saleh E. Hydrocarbon degradation in relation to cell-surface hydrophobicity among bacterial hydrocarbon degraders from petroleum-contaminated Kuwait desert environment. Int Biodeterior Biodegr 2009;63:273-9.

35. Torres S, Pandey A, Castro G. Organic solvent adaptation of gram positive bacteria: Applications and biotechnological potentials. Biotechnol Adv 2011;29:442-52.

36. Ianeva O. Mechanisms of bacteria resistance to heavy metals. Mikrobiol Z 2009;71:54-65.

37. Zscheck K, Murray B. Evidence for a staphylococcal-like mercury resistance gene in Enterococcus faecalis. Antimicrob Agents Chemother 1990;34:1287-9.
38. Saranraj P, Reetha D, Mythili K, Stella D. Bioadsorption of chromium resistant Enterococcus casseliflavus isolated from tannery effluents. J Ecobiotechnol 2010;2:17-22.

39. Megharaj M, Avudainayagam S, Naidu R. Toxicity of hexavalent chromium and its reduction by bacteria isolated from soil contaminated with tannery waste. Curr Microbiol 2003;47:51-4.

40. Chaturvedi M. Studies on chromate removal by chromium-resistant Bacillus sp. isolated from tannery effluent. J Environ Prot (Irvine, Calif) 2011;2:76-82.

41. Wang Y. Microbial reduction of chromate. Environmental MicrobeMetal Interactions. Washington, DC: ASM Press; 2000. p. 225-35.

42. Horitsu H, Futo S, Miyazawa Y, Ogai S, Kawai K. Enzymatic reduction of hexavalent chromium by hexavalent chromium tolerant Pseudomonas ambigua G-1. Agric Biol Chem 1987;51:2417-20.

43. Laukova A, Kmet V. Metal ion resistance of the bacteriocin producing enterococci. Asian Aust J Anim Sci 1993;6:441-5.

44. Laplace J, Boutibonnes P, Auffray Y. Unusual resistance and acquired tolerance to cadmium chloride in Enterococcus faecalis. J Basic Microbiol 1996;5:11-2.

45. Yoon K, Silver S. A second gene in the Staphylococcus aureus cadA cadmium resistance determinant of plasmid pI258. J Bacteriol 1991; 173:7636-42.

46. Tsai K, Linet A. Formation of a phosphorylated enzyme intermediate by the cadA Cd2+-ATPase. Arch Biochem Biophys 1993;305:267-70.

47. Endo G, Silver S. CadC, the transcriptional regulatory protein of the cadmium resistance system of Staphylococcus aureus plasmid pI258. J Bacteriol 1995;177:4437-41.

48. De Niederhäusern S, Bondi M, Anacarso I, Iseppi R, Sabia C, Bitonte $\mathrm{F}$, et al. Antibiotics and heavy metals resistance and other biological characters in enterococci isolated from surface water of Monte Cotugno Lake (Italy). J Environ Sci Heal Part A 2013;48:939-46.

49. Kafilzadeh F, Afrough R, Johari H, Tahery Y. Range determination for resistance/tolerance and growth kinetic of indigenous bacteria isolated from lead contaminated soils near gas stations (Iran). Eur J Exp Biol 2012;2:62-9.

50. Alzahrani O, Ahamed T. Isolation and characterization of heavy metal resistant Bacillus subtilis spp. Collected from water sources of taif province of Saudi Arabia. Int J Curr Microbiol Appl Sci 2015;4:350-7.

51. Beveridge T, Fyfe W. Metal fixation by bacterial cell walls. Can J Earth Sci 1985;22:1893-8.

52. Bruins M, Kapil S, Oehme F. Microbial resistance to metals in the environment. Ecotoxicol Environ Saf 2000;45:198-207.

53. Apell H. How do P-type ATPases transport ions? Bioelectrochemistry 2004;63:149-56.

How to cite this article:

Huët MAL, Puchooa D. Bioremediation of heavy metals from aquatic

environment through microbial processes: A potential role for probiotics?

J App Biol Biotech. 2017;5(6):14-23. DOI: 10.7324/JABB.2017.50603. 